\title{
Prevalence and Determinants of Undernutrition among School Age Slum Children in Dhaka City, Bangladesh
}

\author{
Yeasmin $\mathrm{S}^{*}$ and Islam $\mathrm{K}$ \\ Institute of Nutrition and Food Science, University of Dhaka, Dhaka, Bangladesh
}

${ }^{*}$ Corresponding author: Yeasmin S, Institute of Nutrition and Food Science, University of Dhaka, Dhaka, Bangladesh, E-mail: sharmin12infs@gmail.com

Citation: Yeasmin S, Islam K (2016) Prevalence and Determinants of Undernutrition among School Age

Slum Children in Dhaka City, Bangladesh. J Nutr Health Sci 3(2): 201. doi: 10.15744/2393-9060.3.201

Received Date: February 22, 2016 Accepted Date: May 23, 2016 Published Date: May 25, 2016

\begin{abstract}
The study was aimed at assessing the prevalence of undernutrition and establishing the relationship between prevailing sociodemographic and environmental factor and undernourishment of children aged 6-12 years in four selected slums in Dhaka City, Bangladesh. It was a descriptive cross sectional study conducted among 100 slum children. Their nutritional status was determined by collecting anthropometric data using standard technique and analyzed according to World Health Organization (WHO) guidelines. The sociodemographic and environmental variables of interest were analyzed to find out the determinants of undernutrition in the children. A total of $60 \%$ children were stunted and $84 \%$ were underweight. Being dropout from school, low educational level of parents, mud floor house, low meal frequency, poor hygiene practices (such as, using temporary latrine, not taking bath regularly, drink unboil water) were significantly associated with being underweight and stunted. Similarly, the risk of stunting increased significantly with an increased total family member and number of people living in a room. Children who belong to the family using wood as fuel and who had smoking behaviour were also likely to be stunted.
\end{abstract}

Keywords: Undernutrition; School children; Slum; Stunting; Underweight

\section{Introduction}

Health affects not only current well being and future outcomes at individual and society level but also directly reflect the efficiency of healthcare system and the influence of surrounding environment. Globally, a major public health concern is malnutrition among school age children. The numbers of school age stunted children are more than 200 million [1] and it is estimated that close to one billion children will be physically and mentally impaired by 2020 , if interventions are not carried out $[2,3]$.

Undernutrition makes the child more vulnerable to morbidity and mortality [4,5] and has been linked to delayed mental development [6], poorer educational attainment and lower intellectual and physical abilities in adult life [7]. Bangladesh has the highest number of slum dwellers - $60 \%$ of the urban population- in the South Asian region [8]. The report titled "Human development in South Asia 2014-urbanization: challenges and opportunities" says, the effects of such "unplanned" urbanization has left the urban population with inadequate facilities like too little access to housing, water and sanitation, solid waste management, energy consumption, health and education.

In slum children compared to children living in developed cities are as the extent of malnutrition is found to be much more severe and sometimes even compared to rural regions $[9,10]$. The situation is even poorly because slum dwellers are exposed to poor environmental condition (i.e., overcrowding, poor quality drinking water, sanitation and no removal of waste, low healthcare use, poor diet and lack of knowledge [11].

Nutritional deprivation is rampant in children, particularly primary school age children ranging in magnitude from $20 \%-80 \%$. Since deficient physical growth is naturally reflected in their suboptimal mental development [12]. Half of all deaths and 28\% of stunting in children occur worldwide because of undernutrition. In one of the largest studies in anthropometric status of school age children in low income countries like Bangladesh, stunting and underweight to be high, ranging from $48-56 \%$ for stunting and from $34-62 \%$ for underweight, respectively $[13,14]$. 
Therefore, the malnutrition problem of school age slum children is of foremost importance to all nations as this group forms the future generation [15]. Hence, the present study attempted to identify the factors that are responsible for the problem of school age children of Dhaka city, Bangladesh. So that a basis for planning strategic intervention program can be undertaken from the result of this study, which will improve their health, physical growth and development, school academic performance and progress in whole life.

\section{Materials and Methods}

The present descriptive cross sectional study was conducted in the four selected slum area of Dhaka City, which focused on the health and nutritional status of slum children aged 6-12 years old. This study was carried out from February 2015 to April 2015.

To determine the sample size two stage purposive random sampling techniques were adopted. At first, four study locations were randomly selected, namely Kamlapur, Kawran Bazar, Lalbagh and Kalimondir slum are. Secondly, 25 individuals in each location were included in the study by purposive random sampling method making a total of 100 children. Based on 70\% prevalence [16], 95\% CI (Confidence Interval) and 5\% precision, the sample size was estimated by Eq. (1).

$$
n=z^{2} \frac{p q}{d^{2}}
$$

By this equation sample size was estimated 322, but due to time constrains and lack of resources we had to take 100 samples. The purpose and nature of the study were explained to the participants and their families, and after verbal consent they were recruited to the study. The data were collected by interviewing and examining the participants with the help of their guardians.

Anthropometric measurement technique was used for assessing nutritional status by measuring weight and height of the children. During the measurement of weight each subject was asked to be barefooted and removed heavy cloths to record the data in $\mathrm{kg}$ by using standard weighing machine. Weight was measured to the nearest $0.1 \mathrm{~kg}$. For measuring the height the subjects were requested to stand barefooted on the platform of wooden stadiometer with their head upright and looking straight forward, so that, the shoulders, the buttocks and the heels touch the vertical measuring board. Height was measured to the nearest $0.1 \mathrm{~cm}$. Body Mass Index (BMI) and height for age-Z-score (HAZ) was computed to assess underweight and stunting, respectively using WHO reference values [17]. Underweight was defined as BMI below 18.5 and stunting was defined $\mathrm{HAZ}<-2$ SD (Standard Deviation).

Data were entered and analyzed by SPSS 19 and ENA. Chi-square test and Fisher Exact test were used for testing the significance and association between sociodemographic and environmental characteristics of child and prevalence of undernutrition. Bivariate logistic regression analysis was used to quantify the magnitude of association between different factors and undernutrition. The risk factors entered into the logistic regression that showed statistically significant or close to significant association $(\mathrm{p}$-value $<0.05)$. The explanatory variable entered into the binary logistic regression model were sociodemographic characteristics of children (parent's educational level, occupation of mother, total family member, job status of child, educational status of child), environmental and child characteristics (meal-frequency, floor nature, fuel type, number of person living in a room, are they drinking water type, take bath regularly or not, type of toilet, cutting nail regularly, smoking behaviour). The outcome variables included in the regression model were underweight and stunting. A P-value less than 0.05 were considered as statistically significant.

\section{Results}

A total of 100 school age slum children aged between 6-12 years were included in the study. Table 1 shows general characteristics of child. Majority (41\%) of participants were in the age range 11-12 years old and most of them are males (66\%). Half of the participants were being dropped out from school. Regarding education status of parents, only $29 \%$ and $30 \%$ father and mother of the children received primary education, respectively, whereas, majority of them were illiterate. As regard to mother's occupation, $51 \%$ mothers were worker compared to $49 \%$ were housewives.

Most of the respondents were contained 5-8 family members (54\%) and children were more likely to have job (57\%) than remaining jobless (47\%). More than half of the studied children had daily meal intake 3-4 times a day and belong to family living 5-8 persons in a room, accounting $56 \%$ and $58 \%$, respectively. In terms of sanitation practices, $61 \%$ respondents used boiled water. It was also found that, although almost all the participants (92\%) wash hand before meal, but majority (53\%) said that they don't take bath regularly.

Moreover, this study revealed, 56\% of respondents were more tend to use temporary latrine compared to only $36 \%$ participants who use sanitary latrine and remaining used open latrine. In addition, more participants (59\%) had smoking tendency.

Figure 1 illustrates that, the overall nutritional status of children revealed that $84 \%$ children were underweight and $60 \%$ children were stunted. 


\begin{tabular}{|c|c|c|c|}
\hline Variable & Category & Frequency & (\%) \\
\hline \multirow{3}{*}{ Age } & $6-8$ & 21 & 21 \\
\hline & $9-10$ & 38 & 38 \\
\hline & $11-12$ & 48 & 48 \\
\hline \multirow{2}{*}{ Sex } & Male & 66 & 66 \\
\hline & Female & 34 & 34 \\
\hline \multirow{2}{*}{$\begin{array}{l}\text { Educational status } \\
\text { of children }\end{array}$} & Yes & 50 & 50 \\
\hline & No & 50 & 50 \\
\hline \multirow{3}{*}{$\begin{array}{l}\text { Education level of } \\
\text { father }\end{array}$} & Primary & 29 & 29 \\
\hline & $\begin{array}{l}\text { No schooling (only } \\
\text { signature) }\end{array}$ & 26 & 26 \\
\hline & Illiterate & 55 & 55 \\
\hline \multirow{3}{*}{$\begin{array}{l}\text { Education level of } \\
\text { mother }\end{array}$} & Primary & 30 & 30 \\
\hline & $\begin{array}{l}\text { No schooling (only } \\
\text { signature) }\end{array}$ & 20 & 20 \\
\hline & Illiterate & 50 & 50 \\
\hline \multirow{3}{*}{$\begin{array}{l}\text { Total family } \\
\text { member }\end{array}$} & $0-4$ & 33 & 33 \\
\hline & $5-8$ & 54 & 54 \\
\hline & $>8$ & 13 & 13 \\
\hline \multirow{2}{*}{$\begin{array}{l}\text { Occupation of } \\
\text { mother }\end{array}$} & Worker & 51 & 51 \\
\hline & Housewife & 49 & 49 \\
\hline \multirow{2}{*}{ Do you have job } & Yes & 57 & 57 \\
\hline & No & 43 & 43 \\
\hline \multirow{3}{*}{$\begin{array}{l}\text { Number of person } \\
\text { living in a room }\end{array}$} & $1-4$ & 37 & 37 \\
\hline & $5-8$ & 56 & 56 \\
\hline & $>8$ & 7 & 7 \\
\hline \multirow{3}{*}{ Meal frequency } & $1-2$ & 26 & 26 \\
\hline & $3-4$ & 58 & 58 \\
\hline & $5-6$ & 16 & 16 \\
\hline \multirow{2}{*}{ Do you boil water } & Yes & 39 & 39 \\
\hline & No & 61 & 61 \\
\hline \multirow{2}{*}{$\begin{array}{c}\text { Wash hand before } \\
\text { meal }\end{array}$} & Yes & 92 & 92 \\
\hline & No & 8 & 8 \\
\hline \multirow{2}{*}{$\begin{array}{l}\text { Do you take bath } \\
\text { regularly }\end{array}$} & Yes & 47 & 47 \\
\hline & No & 53 & 53 \\
\hline \multirow{3}{*}{ Types of toilet } & Open place & 8 & 8 \\
\hline & temporary & 56 & 56 \\
\hline & Sanitary & 36 & 36 \\
\hline \multirow{2}{*}{ Cut nail regularly } & Yes & 50 & 50 \\
\hline & No & 50 & 50 \\
\hline \multirow{2}{*}{ Do you smoke } & Yes & 41 & 41 \\
\hline & No & 59 & 59 \\
\hline
\end{tabular}

Table 1: Sociodemographic characteristics and hygiene related information of study participants

Table 2 depicts the result of logistic regression analysis for demographic and environmental variables for determinants of undernutrition $(\mathrm{BMI}<18.5)$. School dropout children had higher odds $(\mathrm{OR}=5.505)$ for worse nutritional status compared to school going groups. The odds for undernutrition were higher in case of illiterate parents compared to literate one. Regarding mother's occupation children belong to housewife mother were associated with an increased risk of underweight than children belong to worker mothers ( $\mathrm{p}$-value 0.036$)$. Odds for meal frequency $(\mathrm{OR}=0.038)$ were also significantly related to undernutrition $(\mathrm{BMI}<18.5)$. Moreover, drinking unboiled water, taking bath irregularly, using temporary latrine and cutting nail irregularly were significantly associated with increased odds of being underweight in the binary logistic regression model (p-value $<0.05)$. Finally, the odds of being underweight were higher among children who had smoking behaviour $(\mathrm{OR}=3.580)$. 


\section{Nutritional status (Body mass index)}

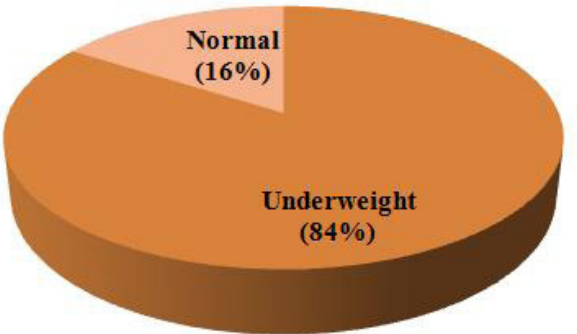

Nutritional status (Height for age)

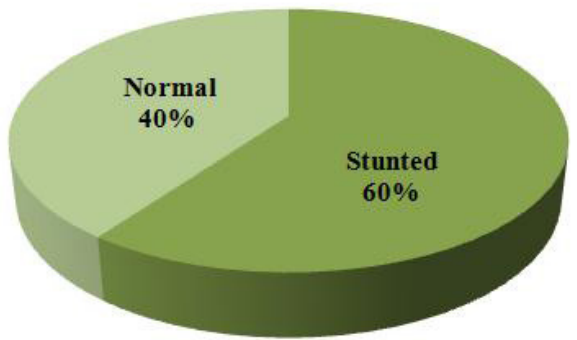

Figure 1: Overall nutritious status of target children

\begin{tabular}{|c|c|c|c|}
\hline Variable & Odd Ratio & $\begin{array}{c}\text { Confidence } \\
\text { Interval (95\%) }\end{array}$ & Significance level \\
\hline \multicolumn{4}{|l|}{$\begin{array}{c}\text { Educational status of } \\
\text { children }\end{array}$} \\
\hline School going & 1 & 1 & \multirow{2}{*}{$\begin{array}{l}X^{2}=7.44 \\
P=0.006\end{array}$} \\
\hline School dropout & 5.505 & $(1.460-20.755)$ & \\
\hline \multicolumn{4}{|l|}{ Education level of father } \\
\hline Primary & 1 & 1 & \multirow{3}{*}{$\begin{array}{l}\mathrm{X}^{2}=8.084 \\
\mathrm{P}=0.019\end{array}$} \\
\hline $\begin{array}{l}\text { No schooling (only } \\
\text { signature) }\end{array}$ & 1.95 & $(0.443-8.579)$ & \\
\hline Illiterate & 5.737 & $(1.585-20.766)$ & \\
\hline \multicolumn{4}{|l|}{ Education level of mother } \\
\hline Primary & 1 & 1 & \multirow{3}{*}{$\begin{aligned} \mathrm{X}^{2} & =10.813 \\
\mathrm{P} & =0.003\end{aligned}$} \\
\hline $\begin{array}{l}\text { No schooling (only } \\
\text { signature) }\end{array}$ & 0.848 & $(0.242-2.970)$ & \\
\hline Illiterate & 8.727 & $(1.711-44.525)$ & \\
\hline \multicolumn{4}{|l|}{ Occupation of mother } \\
\hline Worker & 1 & 1 & \multirow{2}{*}{$\begin{array}{l}X^{2}=4.390 \\
P=0.036\end{array}$} \\
\hline Housewife & 3.462 & $(1.032-11.609)$ & \\
\hline \multicolumn{4}{|l|}{ Meal frequency } \\
\hline $1-2$ & 1.889 & $(0.530-6.727)$ & \multirow{3}{*}{$\begin{array}{l}\mathrm{X}^{2}=6.555 \\
\mathrm{P}=0.038\end{array}$} \\
\hline $3-4$ & 1.522 & $(0.500-4.628)$ & \\
\hline $5-6$ & 1 & 1 & \\
\hline \multicolumn{4}{|l|}{ Do you boil water } \\
\hline Yes & 1 & 1 & \multirow{2}{*}{$\begin{array}{l}\mathrm{X}^{2}=4.422 \\
\mathrm{P}=0.035\end{array}$} \\
\hline No & 3.161 & $(1.044-9.568)$ & \\
\hline \multicolumn{4}{|l|}{ Take bath regularly } \\
\hline Yes & 1 & 1 & \multirow{2}{*}{$\begin{array}{l}\mathrm{X}^{2}=5.994 \\
\mathrm{P}=0.014\end{array}$} \\
\hline No & 4.200 & $(1.250-14.111)$ & \\
\hline \multicolumn{4}{|l|}{ Types of toilet } \\
\hline Open & 1.250 & $(0.270-5.795)$ & \multirow{3}{*}{$\begin{array}{l}\mathrm{X}^{2}=9.282 \\
\mathrm{P}=0.010\end{array}$} \\
\hline Temporary & 3.125 & $(1.301-5.708)$ & \\
\hline Sanitary & 1 & 1 & \\
\hline \multicolumn{4}{|l|}{ Cutting nail regularly } \\
\hline Yes & 1 & 1 & \multirow{2}{*}{$\begin{array}{l}\mathrm{X}^{2}=4.762 \\
\mathrm{P}=0.029\end{array}$} \\
\hline No & 3.632 & $(1.082-12.183)$ & \\
\hline \multicolumn{4}{|l|}{ Do you smoke } \\
\hline Yes & 3.580 & $(0.950-13.493)$ & \multirow{2}{*}{$\begin{array}{c}\mathrm{X}^{2}=3.898 \\
\mathrm{P}=0.048\end{array}$} \\
\hline No & 1 & 1 & \\
\hline
\end{tabular}

Table 2: Logistic regression for undernutrition $(\mathrm{BMI}<18.5)$ in children by sociodemorgraphic and environmental variables 
As shown in Table 3, the odds of stunting were significantly high in school dropout children (OR=2.786, CI=1.215-6.389), children of illiterate parents and children having a housewife mother. Moreover, children belong to family using wood as fuel, 5-8 people living in a room and children who had meal frequency 1-2 times were also associated with increased odds of stunting. The odds of stunting were higher among children who did not drink boiled water (OR=3.161, CI=1.044-9.568) compared to who did. In addition, the likelihood of being stunted was significantly higher among children who did not take bath regularly, used temporary latrine and had smoking behaviour ( $\mathrm{p}$-value $<0.05$ ).

\begin{tabular}{|c|c|c|c|}
\hline Variable & Odd Ratio & $\begin{array}{c}\text { Confidence } \\
\text { Interval (95\%) }\end{array}$ & Significance level \\
\hline \multicolumn{4}{|l|}{ Educational status of children } \\
\hline School going & 1 & 1 & \multirow{2}{*}{$\begin{array}{l}X^{2}=6.00 \\
P=0.014\end{array}$} \\
\hline School dropout & 2.786 & $(1.215-6.389)$ & \\
\hline \multicolumn{4}{|l|}{ Education level of mother } \\
\hline Primary & 1 & 1 & \multirow{3}{*}{$\begin{aligned} \mathrm{X}^{2} & =10.889 \\
\mathrm{P} & =0.004\end{aligned}$} \\
\hline No schooling (only signature) & 2.591 & $(0.810-8.837)$ & \\
\hline Illiterate & 4.916 & $(1.854-13.034)$ & \\
\hline \multicolumn{4}{|l|}{ Total family member } \\
\hline $1-4$ & 1 & 1 & \multirow{3}{*}{$\begin{array}{l}\mathrm{X}^{2}=8.72 \\
\mathrm{P}=0.013\end{array}$} \\
\hline $5-8$ & 3.654 & $(1.470-9.081)$ & \\
\hline$>8$ & 3.462 & $(0.880-13.612)$ & \\
\hline \multicolumn{4}{|l|}{ Occupation of mother } \\
\hline Worker & 1 & 1 & \multirow{2}{*}{$\begin{array}{c}\mathrm{X}^{2}=5.229 \\
\mathrm{P}=0.022\end{array}$} \\
\hline Housewife & 2.600 & $(1.136-5.951)$ & \\
\hline \multicolumn{4}{|l|}{ Job status of children } \\
\hline Yes & 1 & 1 & \multirow{2}{*}{$\begin{array}{c}\mathrm{X}^{2}=10.434 \\
\mathrm{P}=0.257\end{array}$} \\
\hline No & 0.257 & $(0.110-0.599)$ & \\
\hline \multicolumn{4}{|l|}{ Fuel type } \\
\hline Gas & 1 & 1 & \multirow{3}{*}{$\begin{aligned} \mathrm{X}^{2} & =8.297 \\
\mathrm{P} & =0.016\end{aligned}$} \\
\hline Stove & 1.917 & $(0.591-6.214)$ & \\
\hline Wood & 5.167 & $(1.498-17.817)$ & \\
\hline \multicolumn{4}{|l|}{ No. of person living in a room } \\
\hline $1-4$ & 1 & 1 & \multirow{3}{*}{$\begin{array}{c}\mathrm{X}^{2}=5.446 \\
\mathrm{P}=0.066\end{array}$} \\
\hline $5-8$ & 1.889 & $(0.600-5.946)$ & \\
\hline$>8$ & 0.778 & $(0.128-4.721)$ & \\
\hline \multicolumn{4}{|l|}{ Meal frequency } \\
\hline $1-2$ & 3.571 & $(0.984-12.988)$ & \multirow{3}{*}{$\begin{array}{c}\mathrm{X}^{2}=6.460 \\
\mathrm{P}=0.040\end{array}$} \\
\hline $3-4$ & 1.080 & $(0.352-3.313)$ & \\
\hline $5-6$ & 1 & 1 & \\
\hline \multicolumn{4}{|l|}{ Do you boil water } \\
\hline Yes & 1 & 1 & \multirow{2}{*}{$\begin{array}{c}X^{2}=5.178 \\
P=0.023\end{array}$} \\
\hline No & 3.161 & $(1.044-9.568)$ & \\
\hline \multicolumn{4}{|l|}{ Take bath regularly } \\
\hline Yes & 1 & 1 & \multirow{2}{*}{$\begin{array}{c}\mathrm{X}^{2}=7.366 \\
\mathrm{P}=0.007\end{array}$} \\
\hline No & 3.222 & $(1.363-7.618)$ & \\
\hline \multicolumn{4}{|l|}{ Types of toilet } \\
\hline Open & 1.905 & $(0.406-8.943)$ & \multirow{3}{*}{$\begin{array}{c}X^{2}=6.694 \\
P=0.034\end{array}$} \\
\hline Temporary & 2.989 & $(1.256-7.112)$ & \\
\hline Sanitary & 1 & 1 & \\
\hline \multicolumn{4}{|l|}{ Do you smoke } \\
\hline Yes & 3.580 & $(0.950-13.493)$ & \multirow{2}{*}{$\begin{array}{l}X^{2}=9.432 \\
P=0.002\end{array}$} \\
\hline No & 1 & 1 & \\
\hline
\end{tabular}

Table 3: Logistic regression for undernutrition $(\mathrm{HAZ}<-2 \mathrm{SD})$ in children by sociodemorgraphic and environmental variables 


\section{Discussion}

The study approved that, sociodemographic and environmental factors are significantly associated with undernutrition of children. A number of undernourished children are still very high in Bangladesh [17]. In this present study, the overall nutritional status of the children revealed that, $84 \%$ children were underweight and $60 \%$ children were stunted.

A similar study was carried out in Dhaka slums where the prevalence of underweight and stunting was $73.2 \%$ and $68.4 \%$ [17]. That is underweight proportion was slightly lower and stunting rate was slightly higher compared to our study. So, undernutrition is more prevalent in Dhaka slums than the national average, which is $49 \%$ for stunting and $56 \%$ for underweight which indicates exceptionally high levels of undernutrition as judged against WHO criterion [18]. Studies in other countries found out higher rates of stunting, for example- Ethopia 64\%, Bhutan 56\%, India 52\% and Pakistan 50\% [19].

Children age and sex were not associated with undernutrition in the current studies which are different from finding in other similar studies [20,21]. We found that school dropout children were more likely to be stunted and underweight than school going children. A similar study conducted in Nairobi-Peru urban slum found the same result that is those children who did not attend school were more stunted than who did [16]. So there is a positive influence of children's education on their nutritional status. Because schools are vitally important settings for promoting good nutrition and providing nutrition interventions, as to promote health and healthy eating that are more efficient, effective and equal opportunity than another setting [22].

In addition, the findings revealed that parental education was significantly associated with children's undernutrition (Stunting and underweight). Stunting and underweight were more prevalent among children who belong to the illiterate mothers. This result also in agreement with Nabag [23] and Ahmed [24] who conducted their studies in Sudan among the same age group and reported that mother's educational level directly or indirectly causes malnutrition among children and so considered as important underlying determinants of malnutrition. Earlier studies using household level data have found mother's education to be positively associated with a number of measures of child health and nutritional status [25,26]. It is because health friendly measurement is more likely to be adopted by educated mothers and so better nourished children's mothers had better health friendly attitude. Moreover, literate mothers are also better able to manage meager resources to provide essentials and thus having healthier child [27]. This finding is similar to other studies on childhood malnutrition, which showed prevalence of malnutrition was influenced by maternal formal education.

From the findings of this study, father's educational status had significant impact on children to be underweight but it did not have any impact on the stunting of children. Although many studies have proven that education of parents have a positive impact on the health and nutritional status of their children [22]. We found a fairly well and consistent relationship between mother's occupation and undernutrition in children. Housewife mothers were more likely to have undernourished children than working mothers. This may be explained by the fact that financially empowered mother are more spontaneous to spend their income for the welfare of the children, including their nutrition and seeking good medical care at the first sign of a child's illness [27]. This is in agreement with similar studies carried out in Bangladeshi slum [28]. But it is different from another study, which showed children of non-working mother have a better nutritional status than the working mother [29,30].

It was also revealed from this study, children belonging to household 5-8 members were more undernourished than those belonging to household $<5$ members. Similar findings have been depicted in other parts of the world [31-33]. Low levels of child care and low dietary intake could be contributed by a large number of household members [34-36].

In terms of home environmental factor, stunting was more common in children having houses with mud floor than those having houses with cement/brick, which is consistent with the similar study conducted in Ethopia [36], Kaney [37] and Bangladesh [17]. This could be due to the growth of pathogenic organism on the mud floor, which makes children sick and undernourished [38]. Moreover, fuel types, number of people living in a room were significantly associated with undernutrition of children.

Another determinant of undernutrition was meal frequency of child. The prevalence of underweight and stunting was higher among children having meal 1-2 times per day than who have $\geq 3$ times a day, which is similar to another study conducted in Ethopia [36]. The personal hygiene practices of slum children is highly considerable and were identified as important independent predictors of stunting and underweight in this present study. Children residing in household with having a temporary latrine were 3 times more likely to be stunted and underweight compared to children having a sanitary latrine. Latrine used by children has been associated with other studies [39-41].

Similarly, prevalence of undernutrition was higher in children drinking unboiled water. It's because children born into a house without access to clean water were shown to be at risk of disease which ultimately increased the risk of malnutrition, according to a study based on the findings of Bangladesh National Health Survey from 2004 to 2005 [42]. Other factors that were significantly associated with stunting and underweight were children's practices of not taking a bath and cutting nail regularly, and their smoking behaviour. 


\section{Conclusion}

The present study demonstrates the multiple risk factors for childhood undernutrition encompassing sectors other than health alone, including social and environmental sectors. The findings of this study revealed that, the prevalence of underweight children is high in urban slums of Dhaka city with stunting affecting a large number of school going children. Being school dropout, illiterate and housewife mothers, large family size, were associated with increased risk of stunting and children to be underweight, poor home environment, low quality of drinking water, using temporary latrine, smoking behaviour and other poor hygiene practices of children were also significantly associated with underweight and stunting.

As education is a key of society and the quality of future human resources depend on the present day children, improvement of nutritional status of children should be given top priority. But, in this study, lack of mother's education and non-working status of mother was an important determinant of child undernutrition. As a result, there are not aware of the significance of their children's schooling. Moreover, many of the school age slum children have to involve in hazardous work to support their families financially, which have a negative impact on child nutritional status.

The undernutrition problem among school age children in a slum is worsen because the living and environmental condition of slum is not satisfactory. Slum dwellers are exposed to poor environmental condition like, overcrowding, lack of basic utility services including portable water, sanitation and drainage. There should be advocacy to get the government to provide better housing and sewage facilities for her populace as environment significantly affects the nutrition and overall well-being of children.

So, sincere efforts should be undertaken to improve nutritional status of school age children with multipronged approach, such as, giving priority to education for slum children by enough access to government schools in slum areas, literacy program for uneducated mothers for creating awareness regarding the benefits of factors like limiting family size, importance of sending their children in schools and to increase nutritional knowledge which can remove a curse of undernutrition from slum children.

\section{References}

1. UNU (2000) Food and Nutrition Bulletin, (Supplement) UNICEF. 21: 6-17.

2. Levels and trends in child mortality report (2011) Estimates developed by UN inter- agency group for child mortality estimation.

3. Global Monitoring Report (2012) Food prices, nutrition, and the millennium development goals.

4. Fenske N, Burns J, Hothorn T, Rehfuess EA (2013) Understanding child stunting in India: a comprehensive analysis of socio-economic, nutritional and environmental determinants using additive quantile regression. PLOS One 8: e78692.

5. McSweeney L, Rapley T, Adamson A (2015) The preschool child, food photography and a parent's bed: a feasibility study to determine acceptable visual data collection methods. J Nutr Health Sci 2: 406.

6. Moestue H, Huttly S (2008) Adult education and child nutrition: the role of family and community. J Epidemiol Community Health 62: 153-9.

7. Siddiqi MN, Haque MN, Goni M (2011) Malnutrition of under-five children: Evidence from Bangladesh. Asian J Med Sci 2: 113-9.

8. Study: half the urban population in Bangladesh slum dwellers, November 18, (2014) Tribune Report Accessed on 11 February 2015.

9. Miyoshi M, Hawap J, Nishi N, Yoshiike N (2015) Nutritional Status of Children and their Mothers, and its Determinants in Urban Capital and Rural Highland in Papua New Guinea. J Nutr Health Sci 2: 102.

10. Glewwe P, Koch S, Nguyen BL (2002) Child nutrition, economic growth, and the provision of health care services in Vietnam in the 1990s. World Bank, Washington, DC, USA.

11. Singh MB, Fotedar R (2015) Studies on the nutritional status of school age children in drought affected desert environment of Western Rajasthan, India. J Nutr Health Sci 2: 202.

12. Fazili A, Mir A, Pandit IM (2012) Nutritional Status of School Age Children (5-14 years) in a Rural Health Block of North India (Kashmir) Using WHO Z-Score System. J Health Allied Sci 11: 1-3.

13. De Onis M, Blössner M, Borghi E (2012) Prevalence and trends of stunting among preschool children, 1990-2020. Public Health and Nutr 15: 142-8.

14. United nations system standing committee on nutrition (2006) Report of the standing committee on nutrition at its thirty-third session. WHO, Geneva, Switzerland.

15. Turconi G, Rossi M, Testa L, Moro S, Roggi C, et al. (2014) overweight, obesity and abdominal obesity in primary school children in Pavia, Northern Italy. J Nutr Health Sci 1: 101.

16. Pryer JA, Rogers S, Rahman A (2004) The epidemiology of good nutritional status among children from a population with a high prevalence of malnutrition. Public Health Nutr 7: 311-7.

17. Srivastava A, Mahmood SE, Srivastava PM, Shrotriya VP, Kumar B (2012) Nutritional status of school-age children - A scenario of urban slums in India. Arch Public Health 70: 8.

18. Food and Agriculture Organization (FAO)/World Health Organization (WHO) (1992) International Conference on Nutrition (Final Report 1992). Rome, FAO/WHO 9-55.

19. SCN News (1993) Nutrition Relevant Action in Tanzania. UNICEF 236.

20. SCN News, Number 25 (2002) School Age Children: Their Health and Nutrition. SCN News 4-14.

21. Shahabuddin AK, Talukder K, Talukder MK, Hassan M, Seal A, et al. (2000) Adolescent nutrition in a rural community in Bangladesh. Indian J Pediatr 67: 93-8. 22. FAO and WHO Healthy Nutrition (1998) An Essential Element of a Health-Promoting School, WHO Information Series on School Health - Document 4. University Press, New York. 8-10. 
23. Nabag FO (2011) Comparative Study of Nutritional Status of Urban and Rural School Girl's Children Khartoum State, Sudan. J Sci Tech 12: 60-8.

24. Ahmed AF (2003) Assessment of the nutritional status of primary school children aged 6-12 years in Khartoum Area. M.Sc. Thesis, Ahfad University for woman, Khartoum, Sudan.

25. Bicego GT, Boerma JT (1993) Maternal education and child survival: a comparative study of survey data from 17 countries. Soc Sci Med 36: $1207-27$.

26. Thomas D, Strauss J, Henriques MH (1991) How does mother's education affect child height. J Human Resources $26: 183-211$.

27. Ndukwu CI, Egbuonu I, Ulasi TO, Ebenebe JC (2013) Determinants of undernutrition among primary school children residing in slum areas of a Nigerian city. Niger J Clin Pract 16: 178-83.

28. Fakir AMS, Khan MWR (2015) Determinants of malnutrition among urban slum children in Bangladesh. Health Econ Rev 5: 22.

29. Gopaldas T, Patel P, Bakshi M (1998) Selected socio-economic, environmental, maternal, and child factors associated with the nutritional status of infants and toddlers. Food Nutr Bul 10: 29-34.

30. Shah SM, Selwyn BJ, Luby S, Merchant A, Bano R (2003) Prevalence and correlates of stunting among children in rural Pakistan. Pediatr Int 45: 49-53.

31. Herrador Z, Sordo L, Gadisa E, Moreno J, Nieto J, et al. (2014) Cross-sectional study of malnutrition and associated factors among school aged children in rural and urban settings of Fogera and Libo Kemkem districts, Ethiopia. Plose One 9: e105880.

32. Novella R (2013) Parental education, gender preferences and child nutritional status: evidence from four developing countries. No 2013-06, ISER Working Paper Series.

33. Elkholy TA, Hassanen NHM, Rasha MSC (2011) Demographic, socio-economic factors and physical activity affecting the nutritional status of young children under five years. J Am Sci 7: 1-12.

34. Khan MMA, Ali S (2010) Malnutrition and associated factors in pre-school children (2-5 years) in district Swabi (NWFP) Pakistan. J Med Sci 10: 34-9.

35. Maseta E, Kogi-Makau W, Omwega AM (2008) Childcare practices and nutritional status of children aged 6-36 months among short- and long-term beneficiaries of the Child Survival Protection and Development Programmes. South African J Clini Nutr 21: 16-20.

36. Degarege D, Degarege A, Animut A (2015) Undernutrition and associated risk factors among school age children in Addis Ababa, Ethiopia. BMC Public Health 15: 375 .

37. Filmer D, Friedman J, Schady N (2009) Development, modernization, and childbearing: the role of family sex composition. World Bank Economics Review 23: 371-98.

38. Mishra VK, Retherford RD (2000) Women's education can improve child nutrition in India. Natl Fam Health Surv Bull 15: 1-4.

39. Huttly SR, Victora CG, Barros FC, Teixeira AM, Vaughn PJ (1991) The timing of nutritional status determination: implications for interventions and growth monitoring. Eur J Clin Nutr 45: 85-95.

40. Islam MA, Rahman MM, Mahalanabis D (1994) Maternal and socio-economic factors and the risk of a severe malnutrition in a child: a case-control study. Eur J Clin Nutr 48: 416-24.

41. Panigrahi A, Das SC (2014) Undernutrition and its correlates among children of 3-9 years of age residing in slum areas of Bhubaneswar, India. Scientific World Journal 719673 .

42. Ahmed N, Barnett I, Longhurst R (2015) Determinants of child undernutrition in Bangladesh literature review, Produced by MQSUN consortium partner, The Institute of Development Studies (IDS).

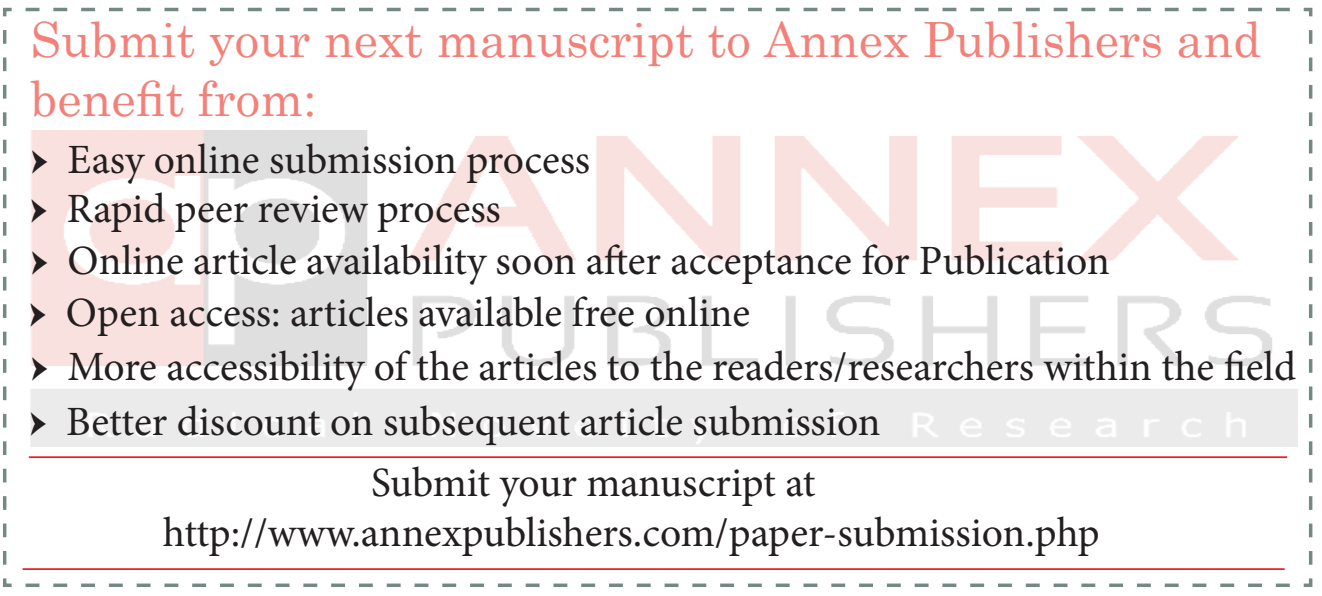

